Di Menna, M. E. (1954). J. gen. Microbiol. 10, 65-67

\title{
Debaryomyces marama n.sp., Isolated from the Air
}

\author{
BY MARGARET E. DI MENNA \\ Department of Microbiology, University of Otago, Dunedin, New Zealand
}

\begin{abstract}
SUMMARY: A new species of Debaryomyces has been isolated from the air. It is characterized by a four-spored ascus, the production of a pellicle, lack of pseudomycelium, and the ability to assimilate glucose, sucrose, maltose and galactose but not lactose.* It has been named Debaryomyces marama.
\end{abstract}

In the course of a survey of aerial yeasts, made with a Manning slit sampler, fifteen strains of a hitherto undescribed species of Debaryomyces were isolated. It is proposed to name this species $D$. marama, from the Maori adjective 'marama' meaning 'light, not dark'.

\section{Debaryomyces marama sp.nov.}

Cellulae in culturis novis rotundae aut subovoidae, singulae aut in racemis parvis, gemmantes multifarium $(2 \cdot 5-6 \cdot 5) \times(2 \cdot 5-5 \cdot 0) \mu$. Pseudomycelium nullum observatum est. Pellicula tenuis sed tenax et arida, sursum repens per latera vasculorum in glucoso cum decocto saccharomycetis (minus biduo $27^{\circ}$ ). Culturae novae in agaro Sabouraudi abundantes, albae, aliae nitidiores, aliae hebetiores, saepe aetate fiunt flavalbidae et subcrispulatae. Copulatio cellularum iniquarum conformationi asci praecedit. Ascosporae rotundae aut subovoidae, glabrae, 1-4 in asco. In ascis tetrasporis sporae in tetrahedram formantur. Interdum fermentatio iniqua glucosi. Glucosum, sucrosum, maltosum, galactosum assimilantur. Lactosum, nitras kalicus non assimilantur. Non crescit $\left(37^{\circ}\right)$.

Cells from young cultures round to slightly oval, single or in small clusters. Budding multipolar. Cell size $(2 \cdot 5-6 \cdot 5) \times(2 \cdot 5-5 \cdot 0) \mu$. No pseudomycelium observed. A light but persistent dry pellicle which spreads up the sides of the tubes in glucose yeast extract broth held at $27^{\circ}$ for less than 2 days. Young cultures on Sabouraud agar abundant, white and glistening to matt, often becoming light fawn and wrinkled with age. Heterogamous conjugation precedes ascus formation. Spores round to slightly oval, smooth, and one to four per ascus. In four-spored asci the spores arranged in tetrahedra. Glucose occasionally weakly fermented. Glucose, sucrose, maltose and galactose assimilated; lactose and potassium nitrate not assimilated. No growth at $37^{\circ}$.

\section{DISCUSSION}

This yeast is included in the genus Debaryomyces as emended by Lodder \& van Rij (1952) (at present a 'nomen conservandum' because of these authors' proposition that the type species, the fermentative $D$. globosus, be excluded).

* Miss W. Sloof of the Yeast division, Centraalbureau voor Schimmelcultures, reports that the strain deposited there assimilated lactose when vitamins were added to the auxanographic medium. In the tests made in this laboratory growth factors were supplied to the medium in the form of a drop of a solution of Difco yeast extract. 
The essential characters in their definition of the genus are as follows. Cells round to short oval. Vegetative reproduction by multilateral budding. A primitive pseudomycelium may be formed. Generally heterogamous conjugation precedes ascus formation. Spores round, usually one per ascus, seldom two, exceptionally up to four (see Fig. 1). A dull, dry, creeping pellicle may be formed. No fermentation or very weak fermentation. Nitrate not assimilated.
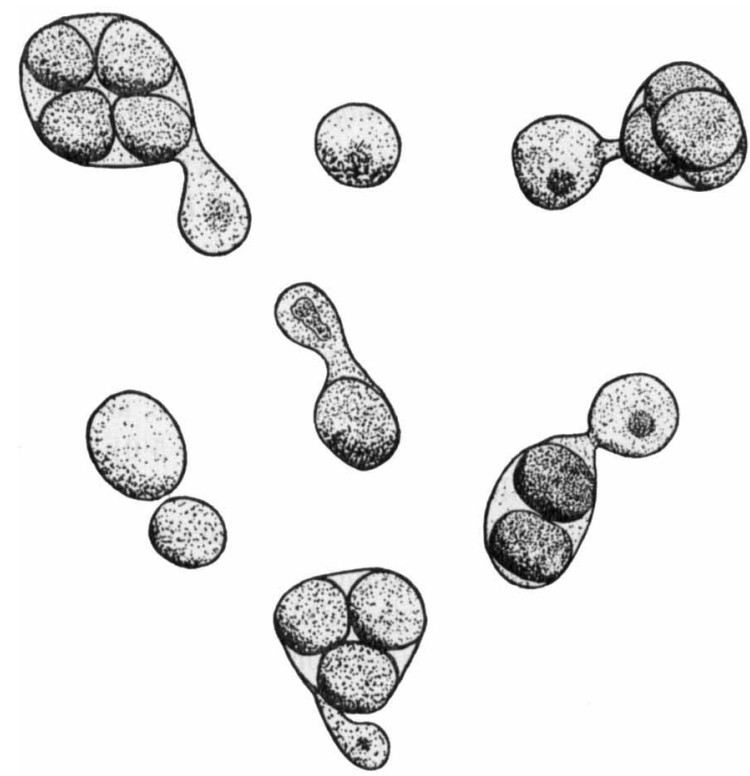

Fig. 1. Asci and ascospores of Debaryomyces marama. From Gorodkowa agar.

D. marama differs from $D$. vini, hitherto the only four-spored Debaryomyces described, in its lack of pseudomycelium and its ability to produce a rapidly formed pellicle, whilst resembling it in the sugars which it can assimilate. Presence or absence of a pseudomycelium of a primitive type is not, in the yeasts, a sufficiently reliable character upon which to separate species, but ability or lack of ability to form a pellicle is, and has been used as the distinction between other Debaryomyces species (D. hansenii and D. subglobosus; D. nicotianae and D. kloeckeri).

Lodder \& van Rij consider that $D$. vini is intermediate between the genera Debaryomyces and Pichia, resembling Pichia in its four-spored asci and pseudomycelium, but lacking a pellicle so that its inclusion in that genus is impossible. By this example, therefore, it would seem that $D$. marama should be placed in Pichia. Nevertheless, I feel that it would be improper to do so. Its resemblance to $D$. vini; its lack of pseudomycelium; the shape of its cells, typical of Debaryomyces and not the long-oval of Pichia, place it in the Debaryomyces. Ecologically also its distribution puts it with Debaryomyces, for all the species of this genus and none of Pichia have been found in the course of the survey on aerial yeasts. 
A strain of this yeast has been dispatched to the Centraalbureau voor Schimmelcultures (Yeast Division), Delft. Strains are also being sent to the Institute of Brewing Yeast Collection, Nutfield, Surrey, and to the American Type Culture Collection.

I wish to thank Prof. G. R. Manton, Classics Department, Otago University, for assistance with the preparation of the Latin diagnosis.

\section{REFERENCE}

Lodder, J. \& Kreger-van RIJ, N. J. W. (1952). The Yeasts. Amsterdam: NorthHolland Publishing Company.

(Received 12 June 1953) 